\begin{abstract}
Iranica
Abstracta Iranica Revue bibliographique pour le domaine irano-aryen

Volume 32-33 | 2013

Comptes rendus des publications de 2009-2010
\end{abstract}

\title{
Yayoi Kawahara. Makhdumzadas in the Khanate of Khoqand
}

\section{Alexandre Papas}

\section{(2) OpenEdition}

1 Journals

\section{Édition électronique}

URL : http://journals.openedition.org/abstractairanica/40315

DOI : 10.4000/abstractairanica.40315

ISSN : 1961-960X

Éditeur :

CNRS (UMR 7528 Mondes iraniens et indiens), Éditions de l'IFRI

\section{Édition imprimée}

Date de publication : 1 décembre 2013

ISSN : 0240-8910

\section{Référence électronique}

Alexandre Papas, "Yayoi Kawahara. Makhdumzadas in the Khanate of Khoqand ", Abstracta Iranica [En ligne], Volume 32-33 | 2013, document 373, mis en ligne le 01 juillet 2016, consulté le 03 octobre 2020. URL : http://journals.openedition.org/abstractairanica/40315 ; DOI : https://doi.org/10.4000/ abstractairanica. 40315

Ce document a été généré automatiquement le 3 octobre 2020.

Tous droits réservés 


\title{
Yayoi Kawahara. Makhdumzadas in the Khanate of Khoqand
}

\author{
Alexandre Papas
}

\section{RÉFÉRENCE}

Yayoi Kawahara. « Makhdumzadas in the Khanate of Khoqand ». Annals of Japan Association for Middle East Studies, 25/2, 2009, p. 104-108. [in Japanese]

1 Cette brève notice présente un résumé en anglais de la thèse de doctorat de l'auteur. Elle offre un accès aux lecteurs non-japonisants qui apprendront que ladite thèse se divise en cinq chapitres et un supplément. Consacré aux MaHdūmzādas, plus exactement à certaines lignées issues du cheikh naqšbandī Aḥmad Kāsānī (m. 1542), ce travail de recherche détaille les biographies de maîtres importants, en particulier Ḥasan Hुvāja (m. 1726). L'A. s'intéresse essentiellement à la vallée du Ferghana durant le khanat de Kokand, à travers différents lignages soufis (y compris mujaddidīs) dont l'histoire se poursuivit tout au long du XIX ${ }^{\mathrm{e}}$ siècle. D'après cet aperçu, on peut supposer que la thèse de Mme Kawahara fournit un matériel historique intéressant pour une analyse plus fine de cette période.

\section{AUTEURS}

\section{ALEXANDRE PAPAS}

CNRS, Paris 